\title{
MODERN INFORMATION TOOLS: THEIR PLACE IN STUDENTS' EXTRA-CURRICULUM AND INVOLVEMENT OF THEM IN MOTOR ACTIVITY OF HEALTH RELATED ORIENTATION
}

Yurchyshyn Y.V.

Kamyanets-Podilsky Ivan Ohienko National University

\begin{abstract}
Purpose: to determine place and role of modern information tools in formation of motivation for health related motor functioning. Material: in the research 150 boys and 150 girls participated. All they were questioned. Results: we have determined that in hierarchy of students' functioning in extra-curriculum time its general kinds prevail. Special kinds of health related motor functioning take unfairly low position. Among general kinds of functioning Internet dominates. We found that health related motor functioning takes low position in general hierarchy: only $2 \%$ of girls and $5.3 \%$ of boys use it in form of training of favorite kind of sports; accordingly $8 \%$ and $6 \%$ - in the form of walks in the open air. Conclusions: it is necessary to uses students' preferences of Internet for their involvement in health related motor functioning.
\end{abstract}

Key words: students, extra-curriculum time, motivation, carrier of information, Internet, health related functioning.

\section{Introduction}

Health related motor functioning of students is realized in curriculum and extra-curriculum forms [8; 9]. Extracurriculum forms are realized in extra-curriculum time. It can be regarded as opportunity for student's free choice of kind of leisure [1; 4]; of entertainment; individual progressing; health related motor functioning; for solution of different tasks [1]. Extra-curriculum time is an important and determining element in aspect of health related motor functioning's systemic realization by students [3;12, 13-18].

In this connection information about students' functioning in extra-curriculum time is rather important and necessary: first of all for optimization of this functioning; for students' involvement in health related motor functioning $[2,5,11-12,19,20]$. Students' extra-curriculum functioning can be divided into general and special kinds. Special kinds can be characterized by health related orientation. Alongside with it some problems of organization of students motor functioning have still been remaining unsolved. In context of recent orders of Ministry of education and Decrees of Cabinet of Ministers students' extra-curriculum functioning has been becoming rather topical (http://mon.gov.ua/usinovivni/novini/2015/09/18/mizhvidomcha-robocha-grupa-fizvixovannya/).

Purpose, tasks of the work, material and methods

The purpose of the research is to determine place and role of modern information tools in formation of motivation for health related motor functioning.

The tasks of the research: determination of directions of students extra-curriculum functioning; determination of different information carriers' priority for students in mastering of academic disciplines; find out students' preferences concerning information carriers' usage for formation of health related knowledge; to study distribution of out-of-class time into different kinds of functioning by students.

The following methods of research were used: general (generalization of literature sources information), oral and written questioning, mathematical - statistic methods. The base of the research: Kamyanets-Podilsky Ivan Ohienko National University, Prikarpatskiy Vasil Stefanik national university and Ternopol Vladimir Gnatiuk national pedagogic university. In the research 150 boys and 150 girls participated. All students studied at different faculties, except faculty of physical education.

Results of he research

Questioning results showed that in extra curriculum time HEE girls try to achieve general aims: $44.7 \%$ - work in Internet; $21.3 \%$ - passive rest; $8 \%$ of boys and $8 \%$ of girls - communication with friends and watching TV; $7 \%$ computer games (see table 1). With it orientation of students' activity in Internet (from total 44.7\%) is as follows: $28.7 \%$ - communicative; $16 \%$ - entertaining; $1.3 \%$ - learning.

As for special kinds of functioning, they are represented by practicing of favorite kind of sports $-2 \%$; walks in the open air $-8 \%$ of students.

(c) Yurchyshyn Y.V., 2015

http://dx.doi.org/10.15561/20755279.2015.0307 
Table 1

Directions of students' functioning in extra-curriculum time

\begin{tabular}{|c|c|c|}
\hline \multirow{2}{*}{ Description of functioning } & \multicolumn{2}{|c|}{ Quantity of respondents, $\%$} \\
\hline & Girls $(n=150)$ & Boys $(n=150)$ \\
\hline \multicolumn{3}{|l|}{ General kinds } \\
\hline Watching TV & 8.0 & 6.7 \\
\hline Communication with friends & 8.0 & 10.0 \\
\hline $\begin{array}{l}\text { Work in Internet: } \\
\text { - cognitive }\end{array}$ & - & 0.7 \\
\hline - entertaining & 16.0 & 12.7 \\
\hline - learning & 1.3 & 1.3 \\
\hline - communicative & 28.7 & 26.0 \\
\hline Reading fictions, newspapers, magazines & - & - \\
\hline Computer games & 6.7 & 12.6 \\
\hline Passive rest & 21.3 & 18.7 \\
\hline \multicolumn{3}{|c|}{ Special kinds, connected with health related motor functioning } \\
\hline Practicing of favorite kind of sports & 2.0 & 5.3 \\
\hline Walks in the open air & 8.0 & 6.0 \\
\hline
\end{tabular}

Analyzing boys' data we registered analogous results but with certain specific features. In particular, boys prefer to spend free time in Internet with the following aims: communicative $-26 \%$; entertaining $-12.7 \%$; learning $-1.3 \%$; cognitive $-0.7 \%$ (see table 1). Passive rest dominates in structure of general kinds of activity in $18.7 \%$ of boys: communication with friends - 10\%; watching TV - 6.7\%. At the same time no one respondent (among boys and girls) preferred reading fiction, newspapers and magazines to other kinds of functioning. It witnesses about low status of such information carrier among.

In respect to health related motor functioning we found the following: only $6 \%$ of boys practice walks in the open air and 5.3\% - practice sports. Detail analysis of the mentioned above data from position of time for realization of different kinds of functioning showed the following: $58 \%$ of girls spend more than 3 hours for communication in Internet; $50.7 \%$ - for entertainment; $5.3 \%$ - for satisfaction of cognitive demands; $4.7 \%$ - for learning. Ежедневной работе в Интернет от 1 до 3 часов отводят 25,3\% девушек (соответственно 30\%, 12,7\% и 7,3\%); до 1 часа - 14\% (accordingly 11.3\%, 18.7\% and 9.3\%) (see table 2). At the same time for reading of books and periodic only 5.3\% of girls spend more than 3 hours every day; $8 \%-0$ from one to three hours and $12 \%$ - up to one hour. For preparation of home tasks they spend accordingly $12.7 \%, 20.7 \%$ and $65.3 \%$. 
Table 2

Distribution of extra-curriculum time by students in to different kinds of functioning

\begin{tabular}{|c|c|c|c|c|c|c|c|c|c|}
\hline \multirow[t]{2}{*}{ Description of functioning } & \multirow{2}{*}{ 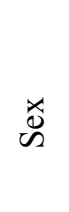 } & \multicolumn{2}{|c|}{ Up to 1 hour } & \multicolumn{2}{|c|}{ Up to3 hours } & \multicolumn{2}{|c|}{$\begin{array}{c}\text { More than } 3 \\
\text { hours }\end{array}$} & \multicolumn{2}{|c|}{ Do not spend time } \\
\hline & & A & $\%$ & A & $\%$ & A & $\%$ & A & $\%$ \\
\hline \multirow{2}{*}{ Watching TV } & $\mathrm{G}$ & 49 & 32.7 & 63 & 42.0 & 22 & 14.7 & 16 & 10.7 \\
\hline & $\mathrm{B}$ & 53 & 35.3 & 57 & 38.0 & 19 & 12.7 & 21 & 14.0 \\
\hline \multirow[t]{2}{*}{ Reading fictions, newspapers, } & $\mathrm{G}$ & 18 & 12.0 & 12 & 8.0 & 8 & 5.3 & 112 & 74.7 \\
\hline & $\mathrm{B}$ & 11 & 7.3 & 6 & 4.0 & 4 & 2.7 & 129 & 86.0 \\
\hline \multirow[t]{2}{*}{ Work in Internet for cognitive } & G & 14 & 9.3 & 11 & 7.3 & 8 & 5,3 & 117 & 78.0 \\
\hline & B & 17 & 11.3 & 7 & 4.7 & 4 & 2.7 & 122 & 81.3 \\
\hline \multirow{2}{*}{ Work in Internet for entertainment } & $\mathrm{G}$ & 17 & 11.3 & 45 & 30.0 & 76 & 50.7 & 12 & 8.0 \\
\hline & B & 24 & 16.0 & 39 & 26.0 & 72 & 48.0 & 15 & 10.0 \\
\hline \multirow[t]{2}{*}{ Work in Internet for communicative } & G & 21 & 14.0 & 38 & 25.3 & 87 & 58.0 & 4 & 2.7 \\
\hline & $\mathrm{B}$ & 25 & 16.7 & 34 & 22.7 & 82 & 54.7 & 9 & 6.0 \\
\hline \multirow[t]{2}{*}{ Work in Internet for learning } & $\mathrm{G}$ & 28 & 18.7 & 19 & 12.7 & 7 & 4.7 & 96 & 64.0 \\
\hline & B & 21 & 14.0 & 26 & 17.3 & 10 & 6.7 & 93 & 62.0 \\
\hline \multirow{2}{*}{ Walks in the open air } & $\mathrm{G}$ & 42 & 28.0 & 14 & 9.3 & 7 & 4.7 & 87 & 58.0 \\
\hline & B & 40 & 26.7 & 17 & 11.3 & 9 & 6.0 & 84 & 56.0 \\
\hline \multirow{2}{*}{$\begin{array}{c}\text { Verbal communication } \\
\text { (communication with friends and }\end{array}$} & $\mathrm{G}$ & 53 & 35.3 & 63 & 42.0 & 34 & 22.7 & - & - \\
\hline & B & 57 & 38.0 & 59 & 39.3 & 34 & 22.7 & - & - \\
\hline \multirow{2}{*}{ Computer games } & $\mathrm{G}$ & 48 & 32.0 & 29 & 19.3 & 11 & 7.3 & 62 & 41.3 \\
\hline & $\mathrm{B}$ & 55 & 36.7 & 22 & 14.7 & 35 & 23.3 & 38 & 25.3 \\
\hline \multirow{2}{*}{ Preparation of academic disciplines } & G & 98 & 65.3 & 31 & 20.7 & 19 & 12.7 & 2 & 1.3 \\
\hline & $\mathrm{B}$ & 92 & 61.3 & 34 & 22.7 & 12 & 8.0 & 12 & 8.0 \\
\hline Другой вариант & $\mathrm{G}$ & - & - & 7 & 4.7 & 4 & 2.7 & - & - \\
\hline (занятия спортом) & $\mathrm{B}$ & - & - & 11 & 7.3 & 6 & 4.0 & - & - \\
\hline
\end{tabular}

Notes: $\mathrm{G}$ - girls; B - boys; A - in absolute values. 
Analysis of girls' special functioning showed the following: walks in the open air take more than 3 hours $4.7 \%$ of girls; within 1-3 hours $-9.3 \%$; up to 1 hour $-28 \%$. Practicing of sports in first two variants was preferred accordingly by $2.7 \%$ and $4.7 \%$ of girls.

The boys were characterized as follows: everyday work in Internet for more than 3 hours with the following purposes: communication $-54.7 \%$; entertainment $-48 \%$; learning $-6.7 \%$; cognitive purposes $-2.7 \%$. From 1 to 3 hours they spend accordingly: $22.7 \%, 26 \%, 17.3 \%$ and $4.7 \%$; up to 1 hour $-16.7 \%, 16 \%, 14 \%$ and $11.3 \%$ of students. At the same time, reading books and periodic took more than 3 hours only $2.7 \%$ of boys; from 1 to 3 hours - $4 \%$; up to 1 hour $-7.3 \%$. Preparation of academic disciplines took accordingly соответственно $8 \%, 22.7 \%$ and $61.3 \%$.

Health related motor functioning in the form of walk in the open air took more than 3 hours of extra curriculum time only $6 \%$ of students; from 1 to 3 hours $-11.3 \%$, up to 1 hour $-26.7 \%$. Physical exercises (in first two variants) took accordingly $4 \%$ and $7.3 \%$ of students (see table 3 ).

In hierarchy of first year students' extra curriculum functioning, its general kinds prevail. Special kinds of health related motor functioning take unfairly low position. Among general kinds work in Internet (application of modern information tools) dominates.

Separately we studied the place of modern information tools in complex of information carriers. It was conditioned by demand in revelation of orientation of knowledge formation as well as skills and intensification of students' cognitive activity in educational process.

Table 3

Significance of different information carriers for students in their mastering academic disciplines

\begin{tabular}{|c|c|c|c|c|c|c|c|c|c|c|}
\hline \multirow{2}{*}{$\begin{array}{c}\text { Information carrier } \\
\text { (by questioning data) }\end{array}$} & \multicolumn{6}{|c|}{ Quantity of respondents with noted degree of information carriers' application, \% } \\
\cline { 2 - 14 } & \multicolumn{2}{|c|}{ Very often } & \multicolumn{2}{|c|}{ often } & \multicolumn{2}{|c|}{ Sometimes } & \multicolumn{2}{|c|}{ Seldom } & \multicolumn{2}{|c|}{ Never } \\
\cline { 2 - 13 } & $\mathrm{G}$ & $\mathrm{B}$ & $\mathrm{G}$ & $\mathrm{B}$ & $\mathrm{G}$ & $\mathrm{B}$ & $\mathrm{G}$ & $\mathrm{B}$ & $\mathrm{G}$ & $\mathrm{B}$ \\
\hline Manuals, recommendations & 25.3 & 22.7 & 37.3 & 34.7 & 20.0 & 26.7 & 17.3 & 16.0 & - & - \\
\hline Search systems of Internet & 70.0 & 65.3 & 21.3 & 24.7 & 8.7 & 10.0 & - & - & - & - \\
\hline Lecture notes & 34.7 & 31.3 & 56.0 & 48.0 & 9.3 & 20.7 & - & - & - & - \\
\hline Electronic manuals & 34.7 & 32.7 & 44.0 & 36.0 & 18.0 & 19.3 & 14.7 & 12.0 & - & - \\
\hline Internet learning sites & 9.3 & 8.0 & 26.0 & 27.3 & 34.7 & 34.0 & 22.7 & 21.3 & 7.3 & 9.3 \\
\hline Teacher's consultations & 8.7 & 7.3 & 9.3 & 11.3 & 26.0 & 25.3 & 39.3 & 34.0 & 16.7 & 22.0 \\
\hline
\end{tabular}

Notes: $\mathrm{G}$ - girls; B - boys.

When studying academic disciplines, in general $79.3 \%$ of girls and $73.3 \%$ of boys prefer information from Internet. Accordingly $23.3 \%$ and $32.7 \%$ - prefer electronic information carriers, available at HEE; $25.3 \%$ and $22.7 \%$ printed information carriers (manuals, recommendations); $34.7 \%$ and $31.3 \%$ - lecture notes; $8.7 \%$ and $7.3 \%$ - teachers' consultations (see table 3). Learning material on health related motor functioning most of students (girls $-60 \%$ and boys - 65.3\%) want to receive with electronic means. Accordingly $19.3 \%$ and $14 \%$ - prefer printed information carriers; $12.7 \%$ and $11.3 \%$ - at seminars; $8 \%$ and $9.3 \%$ - at lectures (see table 4 ). 
Students' preferences in usage of information carriers for formation of health related motor functioning knowledge

\begin{tabular}{|c|c|c|c|}
\hline \multirow{2}{*}{ Information carrier } & \multirow{2}{*}{ Sex } & \multicolumn{2}{|c|}{ Quantity } \\
\hline & & In absolute values & $\%$ \\
\hline \multirow{2}{*}{ Printed } & G & 29 & 19.3 \\
\hline & B & 21 & 14.0 \\
\hline \multirow{2}{*}{ Electronic } & G & 90 & 60.0 \\
\hline & B & 98 & 65.3 \\
\hline \multirow{2}{*}{ Lectures } & G & 12 & 8.0 \\
\hline & B & 14 & 9.3 \\
\hline \multirow{2}{*}{ Seminars } & G & 19 & 12.7 \\
\hline & B & 17 & 11.3 \\
\hline
\end{tabular}

The received data witness that in information carriers' hierarchy of first year students modern information tools dominate over traditional. It is conditioned by simplicity of search, processing and storage of different academic information, as well as by opportunity to improve the quality of independent learning functioning, create favorable conditions for communication, conditions for progressing of creative abilities, intensification and individualization of learning process. As a result cognitive functioning activates and increase of students' motivation for it rises.

\section{Discussion}

Thus, modern information tools are one of the main carriers of academic material, effective mean of students' cognitive functioning activation. Their application in different purposes is of priority in extra-curriculum time as well. It permits to use them for attracting of students to health related motor functioning. For this purpose it is recommended to conduct purposeful training of motivation for realization of such functioning in different forms, in extra-curriculum time.

Thus, physical education is of great importance in students' systemic realization of health related motor functioning. It is assumed to perfect this process in several directions. The found earlier [11-13] extremely low motivation of most of first year students for motor functioning is conditioned by insufficient formation of its procedural and efficient components. In our case they are determining for practicing of health related functioning [3, 6; 10]. These components of motivation are formed in process of physical and intellectual activity [7]. So, perfection of physical education process shall have complex character and include practical and theoretical components.

\section{Conclusions:}

Actual motivation of most of first year students for health related motor functioning in extra-curriculum time is extremely low. Its manifestation takes place only at compulsory physical culture classes. In context of recent requirements of Ministry of education (September 2015) physical education departments shall re-orient their work to extra-curriculum functioning. Most of first year students use Internet in extra-curriculum time. We have found out that in general values' hierarchy health related motor functioning takes low position: only $2 \%$ of girls and $5.3 \%$ of boys practice favorite kinds of sports. Accordingly, 8 and $6 \%$ - prefer walks in the open air. At the same time Internet is the leading tool for them in formation of knowledge, activation of cognitive processes. All these witness about demand in application of Internet for students' involving in health related motor functioning.

\section{Acknowledgement}

The work has been fulfilled in compliance with combined plan of scientific-research works in sphere of physical culture and sports for 2011-2015 by topic 3.9 "Perfection of scientific basis of ports for all, fitness and recreation" (0111U001735). 
It is purposeful to direct further researches for perfection of approaches, methods of usage of modern information tools for formation of students' individual motor functioning programs, knowledge on reasonable distribution of free time, increase of students' motivation for health related motor functioning.

\section{Conflict of interests}

The author declares that there is no conflict of interests.

\section{References:}

1. Bocheliuk VJ, Bocheliuk VV. Dozvillieznavstvo [Study of Leisure]. Kiev: Centre of Educational Literature; 2006. (in Ukrainian)

2. Volkov VL. Osnovi teorii ta metodiki fizichnoi pidgotovki students'koi molodi [Principles of theory and methodic of students' physical training], Kiev: Education Ukraine; 2008. (in Ukrainian)

3. Dekers L. Motivaciia [Motivation]. Moscow: Gross Media; 2007. (in Russian)

4. Dutchak MV. Sport dlia vsikh v Ukraini [Sports for all in Ukraine], Kiev: Olympic Literature; 2009. (in Ukrainian)

5. Iedinak GA. Stan ta deiaki teoretichni aspekti posilennia motivacii studentiv do sistematichnoi rukhovoi aktivnosti ozdorovchogo spriamuvannia [Status and some theoretical aspects of increase of students' motivation for systemic health related motor functioning]. Visnik Prikarpats'kogo nacional'nogo universitetu, 2012;16:67-73. (in Ukrainian)

6. Yermakova TS. Problema formuvannia zdorovogo sposobu zhittia starshoklasnikiv u vitchiznianij pedagogici (druga polovina XX stolittia). Cand. Diss. [Problem of formation of senior pupils' healthy life style in domestic pedagogic (second half of 20th century). Cand. Diss.], Kharkiv; 2010. (in Ukrainian)

7. Zaniuk SS. Psikhologiia motivacii [Psychology of motivation], Kiev: Lybed; 2002. (in Ukrainian)

8. Krucevich TIu. Teoriia $i$ metodika fizichnogo vikhovannia [Theory and methodic of physical education]. Kiev: Olympic Literature, 2008;T1. (in Ukrainian)

9. Krucevich TIu. Teoriia i metodika fizichnogo vikhovannia [Theory and methodic of physical education]. Kiev: Olympic Literature, 2008;T2. (in Ukrainian)

10. Khekgauzen Kh. Motivaciia i deiatel'nost' [Motivation and activity]. Sankt Petersburg: Peter; 2003. (in Russian)

11. Yurchyshyn YV. Tekhnologiia zaluchennia studentiv do rukhovoi aktivnosti ozdorovchoi spriamovanosti u procesi fizichnogo vikhovannia. Cand. Diss. [Technology of students' involving in health related motor functioning in process of physical education. Cand. Diss.], Kiev; 2012. (in Ukrainian)

12. Yurchyshyn YV, Dutchak MV. Efektivnist' eksperimental'noi tekhnologii zaluchennia studentiv do rukhovoi aktivnosti ozdorovchoi spriamovanosti u pokrashchenni pokaznikiv fizichnogo stanu [Effectiveness of experimental technology of students' involving in health related motor functioning, expressed in indicators of physical condition's improvement]. Pedagogics, psychology, medical-biological problems of physical training and sports, 2012;8:130-133. (in Ukrainian)

13. Dudnyk IO. Formation of positive motivation as the basis of students will qualities' perfection in physical culture practicing. Physical Education of Students, 2015;3:3-9. http://dx.doi.org/10.15561/20755279.2015.0301

14. Iermakova TS. Development of the idea of forming health culture of a person in the world educational thought. Pedagogics, psychology, medical-biological problems of physical training and sports, 2014;4:8-12. http://dx.doi.org/10.6084/m9.figshare.950949

15. Iermakova TS. Forming of healthylife style of pupils via prism of physical culture outside of school (historical aspect)ю Pedagogics, psychology, medical-biological problems of physical training and sports, 2011;6:50-56.

16. Ivashchenko OV, Yermakova TS. Assessment of functional, coordination and power fitness of 7-8 form boys. Pedagogics, psychology, medical-biological problems of physical training and sports. 2015;9:20-25. http://dx.doi.org/10.15561/18189172.2015.0903

17. Kozina ZL, Iermakov SS. Analysis of students' nervous system's typological properties, in aspect of response to extreme situation, with the help of multi-dimensional analysis. Physical Education of Students, 2015;3:10-19. http://dx.doi.org/10.15561/20755279.2015.0302

18. Yermakova TS. Individualization of forming health culture in schoolchildren of Polish schools. Pedagogics, psychology, medical-biological problems of physical training and sports. 2015;1:29-33. http://dx.doi.org/10.15561/18189172.2015.0106 
19. Yurchyshyn YV. Students' motivation building technology to motor activity of health improving direction during physical training. Journal of Health Sciences. 2014;2:109-116.

20. Źukowska Hanna, Szark-Eckardt Mirosława, Muszkieta Radosław, Iermakova TS. Characteristics of body posture in the sagittal plane and fitness of first-form pupils from rural areas. Pedagogics, psychology, medical-biological problems of physical training and sports, 2014;7:50-60. http://dx.doi.org/10.6084/m9.figshare.1015583

\begin{tabular}{|c|}
\hline Information about the author: \\
\hline $\begin{array}{l}\text { Yurchushun Y.V.; http://orcid.org/0000-0002-0341-3009; } \\
\text { yuriyyurchyshyn@gmail.com; Kamyanets-Podilsky Ivan } \\
\text { Ohienko National University ; Ivan Ohienko str., 61, } \\
\text { Kamenetz-Podolsky, Khmelnitsky region, 32300, Ukraine. }\end{array}$ \\
\hline $\begin{array}{l}\text { Cite this article as: Yurchyshyn Y.V. Modern } \\
\text { information tools: their place in students' } \\
\text { extra-curriculum and involvement of them in motor } \\
\text { activity of health related orientation. Physical } \\
\text { education of students, } \\
\text { http://dx. doi. org/10.15561/20755279.2015.0407 }\end{array}$ \\
\hline $\begin{array}{l}\text { The electronic version of this article is the complete } \\
\text { one and can be found online at: } \\
\text { http://www. sportpedu. org. ua/html/arhive-e. html }\end{array}$ \\
\hline $\begin{array}{l}\text { This is an Open Access article distributed under the } \\
\text { terms of the Creative Commons Attribution License, which } \\
\text { permits unrestricted use, distribution, and reproduction } \\
\text { in any medium, provided the original work is properly } \\
\text { cited } \\
\text { (http://creativecommons. org/1icenses/by/3.0/deed. en). }\end{array}$ \\
\hline Received: 06.08. 2015 \\
\hline Accepted: 26.08.2015; Published: 30.08. 2015 \\
\hline
\end{tabular}

